\title{
Nasionalisme vs Globalisasi \\ 'Hilangnya' Semangat Kebangsaan dalam Peradaban Modern
}

\author{
Oleh : Grendi Hendrastomo ${ }^{1}$
}

\section{Abstracts}

This article is going to discuss about the conflict between nationalism and globalization in Indonesia. The focus of this article will be more illuminated on the decreasing of causal factor of nationalism.

Nationalism in Indonesia is fading sooner or later and will be replaced by the arousal of ethnicities and globalism. There is a tendency to give more priority to their group's importance and superiority more than what they give to their countries. Beside from the strengthening of ethnicities, openness and modernity which are the products of globalization are undermining our nationalism.

This article will also describe the perspective of world as a global villages where world is as part of the globalization in where the interaction among person is as if it is borderless.

Keywords: Nationalism, Globalisation, Ethnicities, Imagined Community.

\section{A. Pendahuluan}

Di era serba modern, serba terbuka paham nasionalisme semakin terkikis oleh paham globalisme. Kondisi tersebut hampir terjadi di semua negara didunia, tak terkecuali di Indonesia. Kekuatan-kekuatan capital asing semakin merajalela, memperluas jaringannya. Sumber daya alam Indonesia yang melimpah di eksploitasi oleh pihak asing dengan kedok "investasi", dimana keuntungan lebih banyak dinikmati capital asing, secara tidak langsung kita dijajah kembali oleh kekuatan asing.

Dalam kaitannya dengan nasionalisme, maka dapat dilihat bahwa negara hanya dijadikan sebagai alat penjaga keamanan dan

\footnotetext{
1 Staf Pengajar Program Studi Pendidikan Sosiologi Fakultas Ilmu Sosial dan Ekonomi Universitas Negeri Yogyakarta.
} 
ketertiban, sedangkan kemakmuran dan kesejahteraan dikuasai oleh perusahaan-perusahaan multi nasional yang notabene milik asing. Ada kecenderungan pergeseran peran negara kearah itu, dimana nantinya nasionalisme warga negara sedikit demi sedikit akan memudar (nationless) dan diganti dengan paham globalisme yang mendewakan uang dan kesenangan.

Nasionalisme merupakan sebuah paham yang mana muncul tatkala kita diharuskan untuk memilih pada diri kita akan status kebangsaan. Secara umum nasionalisme muncul tatkala seseorang dihadapkan pada dua atau lebih pilihan yang mengharuskannya memilih hal yang berkenaan dengan kewarganegaraan, suatu kelompok, yang secara khayal ada keterikatan.

Warga negara dari suatu bangsa pasti memiliki identitas politik yang mana identitas tersebut ditanamkan semenjak kita lahir, semenjak kita mengenyam pendidikan. Di Indonesia sendiri penanaman konsep identitas politik (politic identity) diwujudkan pada diselenggarakannya peringatan-peringatan yang berkaitan dengan jati diri bangsa, misal, peringatan sumpah pemuda, 17 Agustus, upacara setiap hari senin, dan sebagainya. Yang mana kesemuanya itu merupakan upaya-upaya untuk menumbuhkan kesadaran akan identitas politik dan upaya untuk menanamkan rasa nasionalisme. Mencetak pribadi-pribadi yang cinta dan banga akan bangsanya. "saya adalah orang Indonesia, lahir dan hidup di Indonesia, maka saya harus mengabdi kepada bangsa dan negara saya, apa yang bisa saya lakukan untuk negara?"

Statemen di atas mungkin pada saat ini sudah tidak bisa dipakai atau dijadikan patokan. Hal ini dikarenakan mulai maraknya budaya luar yang notabene mulai mengaburkan batas-batas khayal budaya suatu negara. Di Indonesia orang mungkin tidak lagi bangga akan bangsanya, orang akan cenderung membandingkan dengan bangsa lain, mereka berandai-andai bagaimana kalau mereka tinggal di bangsa/negara lain yang lebih baik daripada Indonesia. Ironisnya negara yang dijadikan pembanding merupakan pencipta dan penyebar arus globalisasi, ilmu pengetahuan dan teknologi yang notabene merupakan negara yang sudah mapan segala-galanya dan menganggap bangsa asia hanya sebagai 'market' bagi keuntungan 
negaranya. Kondisi demikian sudah mewabah hampir disemua kotakota besar di asia pada umumnya dan di Indonesia pada khususnya Hal ini salah satunya disebabkan karena semakin terbukanya informasi, pengaruh kapitalis (globalisasi), ketidakmampuan pancasila dalam menyaring budaya-budaya dan informasi yang masuk dan hal lain yang intinya semakin mendekatkan masyarakat pada konsep 'global village'. Salah satu sebab yang merupakan penyebab utama adalah karena adanya globalisasi.

Diaspora (persebaran) globalisasi yang pesat merupakan penyebab utama kemerosotan rasa nasionalisme. Dengan kata lain globalisasi merupakan tantangan utama bagi nasonalisme tanpa mengenyampingkan factor-faktor lain.

Dalam perkembangan sejarah, paham nasionalisme (kebangsaan) tidak atau belum pernah mengalami tantangan yang sedemikian serius. Dengan merebaknya globalisasi dalam bidang ekonomi yang didukung dengan teknologi komunikasi, mengakibatkan melemahnya batas-batas antar negara, sehingga terjadi interaksi universal antar manusia.

\section{B. Nasionalisme}

Nasionalitas, kebangsaan dan nasionalisme adalah budaya hasil ciptaan manusia yang diciptakan menjelang akhir abad ke 18. Nasionalisme merupakan penyaringan spontan akan sebuah "crossing" yang rumit mengenai kekuatan historis, tetapi sekali diciptakan, mereka kemudian menjadi "modular", dapat ditransplantasikan ke bermacam-macam daerah sosial untuk bergabung dan digabungkan dengan kelompok politik dan ideologis.

Konsep nasionalisme sendiri lahir ketika Ben Anderson mengungkapkan gagasannya tentang masyarakat khayalan (imagined communities). Menurut Anderson ${ }^{2}$ nasionalisme adalah:

"... it is an imagined political community that is imagined as both inherently limited and sovereign".

${ }^{2}$ Anderson, Benedict. (1991). Imagined Communities: Reflection on the Origin and Spread of Nationalism, Revised Edition ed, London and New York: Verso. 
(Nasionalisme adalah sebuah komunitas politik berbayang yang dibayangkan sebagai kesatuan yang terbatas dan kekuasaan tertinggi).

Berbayang karena anggota-angotanya, meskipun bangsa yang paling kecil tidak akan pernah tahu kebanyakan teman, anggota mereka, bertemu dengan mereka atau bahkan mendengar mengenai mereka, tetapi sebaliknya dalam pikiran masing-masing hidup bayangan akan komunitas mereka. Sebagai contoh penduduk desa di Jawa selalu menyadari bahwa mereka terhubung dengan orangorang yang bahkan belum pernah mereka temui. Tetapi secara tidak sadar ikatan ini dibayangkan secara khusus sebagai jaring persaudaraan yang terentang tanpa batas.

Bangsa dibayangkan terbatas karena bangsa yang besar sekalipun memiliki keterbatasan. Adanya ikatan-ikatan elastis diluar, yang disana terdapat bangsa-bangsa lain. Tidak bisa suatu bangsa hidup tanpa bangsa lain, tidak mungkin suatu bangsa mendiami suatu planet, yaitu planet, misal $\mathrm{X}$ yang hanya terdiri dari satu bangsa.

Bangsa dibayangkan sebagai kekuasaan tertinggi karena hal tersebut matang di panggung sejarah manusia ketika kebebasan adalah suatu hal yang langka dan secara idealis berharga. Dan bangsa dibayangkan sebagai komunitas karena dipahami sebagai sebuah persahabatan horizontal yang dalam.

Paham kebangsaan adalah paham yang menyatakan loyalitas tertinggi terhadap masalah duniawi dari setiap warga, yang ditujukan kepada negara dan bangsa.

Nasionalisme berakar dari sistem budaya suatu kelompok masyarakat yang saling tidak mengenal satu sama lain. Kebersamaan mereka dalam gagasan mengenai suatu bangsa dikonstruksikan melalui khayalan yang menjadi materi dasar nasionalisme. Sebagai contoh dalam pandangan Anderson nasionalisme Indonesia terbentuk dari adanya suatu khayalan akan suatu bangsa yang mandiri dan bebas dari kekuasaan kolonial, suatu bangsa yang diikat oleh suatu kesatuan media komunikasi, yakni bahasa Indonesia. Definisi tersebut memang benar apabila dikemukakan 80 tahun yang lalu. Tetapi di masa sekarang bahasa tidak bisa lagi dijadikan 
jaminan untuk mampu membentuk kesatuan nasionalime bangsa. Hal ini disebabkan karena banyaknya tantangan yang dihadapi oleh semangat kebangsaan (nasionalism) itu sendiri.

\section{Globalisasi dan memudarnya semangat kebangsaan (nationless)}

Tantangan bagi nasionalisme lahir seiring dengan semakin modernnya kehidupan manusia dimana jarak bukan lagi suatu halangan, dimana media telekomunikasi telah menyatukan semua lapisan masyarakat menjadi suatu global village. Dalam hal ini, globalisasi telah menjadi ujung tombak dalam mengikis paham nasionalisme. Globalisasi telah menimbulkan problem terhadap eksistensi negara dan bangsa.

Menurut Kwik Kian Gie, Hakikat Globalisasi ialah mekanisme pasar yang diberlakukan untuk seluruh dunia tanpa mengenal batasbatas negara. Mekanisme pasar sendiri secara ekonomi berarti tergantung permintaan pasar yang pada ujungnya berkaitan dengan keuntungan dan kerugian, yang akhirnya akan memecah belah manusia kedalam persaingan yang tidak sehat.

Di sisi lain, bagi sebagian orang globalisasi dipandang sebagai bagian dan proses integrasi manusia, namun bagi yang lainnya globalisasi justru dirasakan sebagai ancaman disintegrasi dan marginalisasi kemanusiaan secara total dan semesta. Robertson mendefinisikan globalisasi sebagai:

"The compression of the world into a single space and the intensification of the world consciousness of the world as a whole".

Ada yang memandang globalisasi sebagai proses perubahan yang bergerak cepat, saling kait mengkait dan mencakup semuanya. Ada yang melihat faktor ekonomi, teknologi dan pengetahuan sebagai faktor utamanya. Ada yang memandang globalisasi sebagai kebangkitan baru kesadaran kemanusian universal.

"Globalization is defined here in term of the increasing scale and speed of exchanges of people, products, services, capital and ideas across international borders." (Lowel Dittmer) ${ }^{3}$

${ }^{3}$ Kinvall and Jonsson. (2002) Globalization and Democratization in Asia, The Contruction of Identity. London. Routledge. Chapter two. 
(Globalisasi didefinisikan sebagai hal yang berkaitan dengan kenaikan skala dan kecepatan bertukar masyarakat, produkproduk, jasa, modal dan ide melintasi batas-batas internasional).

Globalisasi merupakan proses transformasi berbagai dimensi kehidupan sosial manusia yang mengarah kepada suatu pusat budaya kosmopolitan. Arus globalisasi mendesakkan uniformitas secara universal. Secara perlahan, namun pasti, proses universal ini akan mengikis batas-batas identitas negara dan individu secara hampir bersamaan melalui liberalisasi ekonomi dan demokratisasi di tingkat global maupun nasional.

Diamond dan Mc Donald mencoba memetakan hal tersebut dengan mengatakan bahwa dewasa ini penduduk dunia tengah berada di antara dua paradigma. Dunia kini menyaksikan dua gerakan yang secara simultan terjadi pada tatanan internasional. Gerakan pertama adalah gerakan yang mengarah kepada unity (keseragaman) dimana batasan negara menjadi semakin kabur dan dunia seolah-olah diproyeksikan menjadi "global village". Disisi lain, juga terjadi gerakan kedua yang justru mengarah pada diversity (keberagaman). Jadi sementara pada satu sisi kerjasama dan kolaborasi menjadi perhatian utama para aktor dalam sistem internasional, disisi lain, mencuatnya identitas-identitas lokal yang terwujud dalam berbagai gerakan dan tuntutan menjadi potensi konflik baru yang mengancam stabilitas internasional, yaitu kolektifisme versus individualisme.

Globalisme telah menimbulkan perdebatan mengenai otoritas dari negara bangsa (nation-state) sementara pada saat yang bersamaan gerakan separatis, konflik antar etnis dan agama juga mencuat kembali. Negara dihadapkan pada masalah loyalitas warganya, antara individu yang berorientasi ke arah keterikatan global dan pihak yang bergerak ke arah penguatan subnasional. Hal tersebut terutama tampak di Indonesia pasca runtuhnya rezim orde baru. Akibat globalisasi konflik antar etnis dan antar agama, gerakan separatis dan keinginan untuk memerdekakan diri mulai meningkat. Gejala ini diakibatkan oleh karena kurangnya integrasi di negara kita. 
Myron Wiener ${ }^{4}$ mengatakan bahwa level integrasi nasional di Indonesia masih sangat rendah. Salah satu faktanya adalah lepasnya Timor Timur dari tangan Indonesia. Peristiwa tersebut merupakan contoh nyata dampak dari globalisasi yang berakibat mulai lunturnya rasa nasionalisme, diganti dengan etnisitas. Kenapa hal tersebut terjadi? Miroslav Hroch mengatakan bahwa nasionalisme :

“...bertindak sebagai faktor-faktor integrasi dalam suatu masyarakat yang mengalami disintegrasi, ketika masyarakat runtuh, bangsa muncul sebagai penjamin pokok."

Persaingan ekonomi yang keras, keadaan yang lahir akibat globalisasi menyebabkan munculnya konflik di daerah-daerah, konflik antar warga negara asli dan pendatang atau kebijakan imigrasi yang merugikan warga negara asli seringkali menjadi faktor pemicu. Dalam hal ini, nasionalisme menjadi kendaraan bagi prasangka rasial atau xenophobia (ketakutan yang berlebihan pada etnis asing). George Simmel berpendapat bahwa :

"Kelompok-kelompok dan khususnya minoritas-minoritas yang hidup dalam konflik, seringkali menolak pendekatanpendekatan atau toleransi dari 'lawan' mereka. Sifat penolakan mereka yang tertutup, yang tanpa itu mereka tidak bisa berjuang terus akan pudar. Di dalam kelompok-kelompok tertentu, mungkin merupakan semacam kebijakan publik untuk menciptakan musuhmusuh demi efektifnya kesatuan para anggotanya dan demi menyadarkan kelompok bahwa kesatuan ini merupakan kepentingan yang vital."

Akibat pertarungan dua arus besar tersebut yaitu nasionalisme versus globalisasi akan memunculkan skenario universalisme versus partikularisme. Skenario yang pertama adalah arus pertama sebagai pemenang, artinya proses globalisasi akan berjalan mulus hingga proyeksi "world as a global village" akan menjadi kenyataan, yaitu loyalitas individu praktis akan berada dalam konteks keterikatan global. Hal ini akan mengakibatkan "the end of nasionalism". Snyder meramalkan "kiamat" bagi nation-state atas beberapa kecenderungan yaitu:

4 Suryadinata, Leo. (2002). Nationalism and Globalization East and West. Singapore. ISEAS. hal 41. 
1. Meningkatnya komunikasi lintas budaya akan memudarkan konsep identitas.

2. Mergernya isu-isu domestik dan internasional akan mendorong proses internasionalisme

3. Kegagalan negara bangsa dalam mengatasi masalah-masalah global seperti lingkungan hidup, produksi pangan, wabah penyakit dll.

4. Ketidakmampuan negara bangsa untuk memberikan perlindungan secara menyeluruh bagi warga negaranya di era nuklir ini.

5. Nasionalisme mempunyai cacat sejarah sebagai pemicu konflik.

6. Perusahaan Multinasional (MNC) dan economic interdependence telah mengakhiri ide economic nationalism.

Skenario yang kedua (partikularisme) berpendapat :

1. Kecenderungan rekonseptualisasi globalisasi. Arus universalisme mulai dilihat tidak lagi sebagai suatu keharusan sejarah dunia, melainkan suatu proses pembaratan. Para penganut sosiologi postmodernisme secara keras mengkritik proses modernisasi global. Mereka menentang keras asumsi weber yang menyatakan bahwa perubahan masyarakat dunia menuju modern merupakan hal yang tidak terelakan dan globalisasi akan menghilangkan segenap tradisi dalam masyarakat dunia ketiga.

2. Kesalahan-kesalahan kapitalisme di negara-negara dunia ketiga yang tidak sejalan dengan proses nation building turut memberikan kontribusi bagi menguatnya arus globalisasi. Segala bentuk kapitalisme di negara-negara berkembang bermuara pada terciptanya masyarakat yang terfragmentasi secara sosial, ekonomi maupun politik. Vesna Pesic, professor pada University of Belgrde dan pemimpin oposisi di Serbia, mengatakan bahwa pada intinya berbagai konflik etnik yang terjadi disebabkan karena meningkatnya ketakutan dari kelompok etnis (the emergence of collective fear) dalam melihat prospek masa depan. Penegasan identitas kelompok dalam bentuk perlawanan dominasi kelompok lain kemudian akan 
menjadi satu jalan yang ditempuh untuk mendapatkan rasa aman. Dalam hal ini kemajuan teknologi dan komunikasi telah menjadi media yang efektif bagi penyadaran identitas dan penyampaian aspirasi kelompok. Sebagai contoh modernisasi telah menimbulkan persaingan dalam perebutan lapangan kerja, hal ini terjadi pada kasus konflik di Sambas di mana etnis asli merasa terancam oleh kedatangan etnis lain (transmigran). Kasus tersebut menjadi contoh nyata mengapa peran teknologi dan komunikasi menjadi penting untuk membentuk opini atau identitas tertentu (membentuk sentimen identitas).

3. Tersendat-sendatnya proses pembentukan uni eropa yang sebetulnya merupakan test case bagi proses integrasi global, menyiratkan keengganan penyerahan kedaulatan pada batasbatas tertentu yang bahkan masih terdapat di negara-negara maju.

Dari dua skenario di atas universalisme dan partikularisme apabila dikaitkan dengan apa yang terjadi di Indonesia, tampaknya kecenderungan yang terjadi mengarah pada universalisme dimana pancasila yang semula dijadikan filter tidak mampu lagi menyaring arus modernisasi yang terjadi di era globalisasi ini. Akibatnya bangsa kita sekarang ini terjangkit virus merosotnya semangat kebangsaaan, antara lain penyakit governmentless (kurangnya wibawa pemerintah).

Di beberapa tempat rakyat mengungkapkan pembangkangan dan menolak kebijakan pemerintah. Akibatnya hukum sebagai pranata tidak berarti apa-apa. Hal ini terjadi karena hancurnya ikatan kebangsaan di masyarakat Indonesia. Rakyat tidak punya semangat kebangsaan (nationless) seolah-olah bukan warga sebangsa.

Keinginan-keinginan untuk melepaskan diri dari negara kesatuan Republik Indonesia merupakan wacana yang patut kita cermati. Adanya gerakan aceh merdeka, papua merdeka merupakan salah satu contoh semakin hilangnya semangat kebangsaan ditelan oleh eksklusifitas etnis, keinginan untuk merasa lebih baik jika hanya mengelola diri sendiri, dan sebagainya. Kebobrokan tersebut merupakan buah dari pemerintahan yang tidak benar dan buah dari adanya globalisasi yang mampu menyebar luaskan informasi kesegenap penjuru tanah air. Orang akan dengan mudah 
mendapatkan informasi tentang segala sesuatu. Untuk mengetahui kejadian di Jakarta, orang Irian tidak perlu ke Jakarta. Orang ingin berbicara dengan teman yang berbeda wilayah cukup dengan mengunakan telepon atau sms. Kemudahan-kemudahan tersebut merupakan hasil karya globalisasi yang menyebabkan ketergantungan.

Semua penyakit tersebut memang disebabkan karena beberapa hal, tetapi secara kultur kita sudah diaduk-aduk pihak asing selama bertahun-tahun dan kita terlena oleh suara-suara demokrasi dan hak asasi manusia yang terus mereka gemborgemborkan, padahal banyak yang belum memahami demokrasi di negara kita.

Penyebab yang lain adalah semakin mudahnya interaksi universal antar manusia, antar negara tanpa batas-batas. Disamping itu kita tidak mau dikatakan sebagai bangsa yang tertinggal di era global yang melanda dunia ini. Interaksi tanpa batas tersebut tak mustahil mampu memporak-porandakan adat budaya yang menjadi jati diri bangsa yang akan melemahkan paham nasionalisme dan menimbulkan problem terhadap eksistensi negara.

\section{Kesimpulan}

Memudarnya semangat nasionalisme sedikit demi sedikit akan menyebabkan merosotnya peran negara. Kecenderungan munculnya kelompok-kelompok etnis merupakan salah satu bentuk memudarnya nasionalisme. Ditengah maraknya globalisme dengan segala atributnya, berupa modernisasi, keterbukaan, kemudahan dan kemajuan teknologi, merupakan sebuah tantangan bagi eksistensi nasionalisme. Peran kapital asing semakin besar dan ketergantungan negara terhadap pihak asing semakin menyudutkan peran negara di mata warga negara.

Era teknologi komunikasi dengan mewabahnya internet (world wide web) semakin melegitimasi bahwa dunia semakin sempit dan ada kecenderungan kearah dunia sebagai sebuah kesatuan, sebuah kerumunan, masyarakat layaknya negara (world as a global village). Orang bebas berinteraksi satu sama lain tanpa ada sekat. Tanpa dorongan yang kuat dari dalam dan kesadaran warga negara 
Nasionalisme vs Globalisasi 'Hilangnya' Semangat Kebangsaan

akan pentingnya nasionalisme maka lambat laun orang akan semakin individualistis tanpa ada keinginan untuk menjalin keterikatan satu sama lain.

Akhirnya di tengah semakin majunya peradaban dengan teknologi ilmu pengetahuan yang semakin maju, paham nasionalisme diuji apakah akan tetap eksis atau bahkan hilang di telan arus globalisasi atau etnisitas. Nasionalisme barada di posisi yang terjepit antara derasnya arus globalisasi dan kuatnya semangat etnisitas.

\section{Kepustakaan}

Anderson, Benedict. (1991). Imagined Communities: Reflection on the Origin and Spread of Nationalism, Revised Edition ed. London and New York: Verso. http://www.nationalismproject.org/what/anderson.htm

Dewan Pertimbangan Agung. (2000). Pengantar Diskusi Globalisasi sebagai Tantangan Terhadap Masyarakat Indonesia yang di CitaCitakan, Jakarta. http://www.bogor.net/idkf/idkf-2/diskusimenuju-era-globalisasi-dpa-03-2000.rtf

Hendardi, Nasionalisme dan Hak Asasi Manusia. http://mail2.factsoft.de/pipermail/national/2003June/017552.html

Hobsbawn, E.J. (1992). Nasionalisme Menjelang Abad XX. Yogyakarta. Tiara Wacana.

Kian Gie, Kwik. (2006). Nasionalisme dan ke-Indonesia-an http:/ / perpustakaan.bappenas.go.id/pls/kliping/data_acces s.show_file_clp? v_filename=F21997 $/$ Nasionalisme $\% 20$ dan $\% 2$ 0ke-BI.htm

Kinvall and Jonsson. (2002). Globalization and Democratization in Asia, The Construction of Identity. London. Routledge.

Sugiarto, Bima A. "Nasionalisme: Antara Universalisme dan Partikularisme", Jurnal Universitas Paramadina Vol. 1 No. 1, September 2001.

Suryadinata, Leo. (2000). Nationalism and Globalization East and West. Singapore. ISEAS. 